Article

\title{
Effect of Biostimulants and Storage on Discoloration Potential of Carrot
}

\author{
Małgorzata Szczepanek 1,*(D), Jarosław Pobereżny ${ }^{2}$ (D) Elżbieta Wszelaczyńska ${ }^{2}$ and \\ Katarzyna Gościnna ${ }^{2}$ \\ 1 Department of Agronomy, UTP University of Science and Technology, Kaliskiego 7 Street, \\ 85-796 Bydgoszcz, Poland \\ 2 Department of Microbiology and Food Technology, University of Science and Technology, \\ Kaliskiego 7 Street, 85-796 Bydgoszcz, Poland; poberezny@utp.edu.pl (J.P.); wszela@utp.edu.pl (E.W.); \\ katarzyna.goscinna@utp.edu.pl (K.G.) \\ * Correspondence: malgorzata.szczepanek@utp.edu.pl; Tel.: +48-52-374-9465
}

Received: 7 October 2020; Accepted: 25 November 2020; Published: 30 November 2020

check for updates

\begin{abstract}
The application of biostimulants to prevent stress-related losses and increase productivity is becoming an increasingly common practice. A study was carried out to determine the effect of the type and methods of biostimulant application and long-term storage on the content of antioxidant compounds determining the processes of the enzymatic browning of carrot roots. The natural seaweed biostimulant Kelpak and synthetic Asahi were applied as part of the study. A quality assessment of carrot roots was carried out directly after harvest and after six months of storage in air at a temperature of $1{ }^{\circ} \mathrm{C}$ and a relative humidity of $95 \%$. A single application of Kelpak seaweed extract in the four-leaf phase $\left(2 \mathrm{or} 3 \mathrm{dm}^{3} \mathrm{ha}^{-1}\right)$ proved to be the most effective for reducing oxidative darkening processes (by 33.5\%). The oxidative potential was most strongly dependent on the anthocyanin $(r=-0.477)$ and chlorogenic acid $(r=-0.474)$ contents. The concentration of polyphenols $(r=0.836 ; r=0.719)$ and flavonoids $(r=0.671 ; r=0.729)$ had the greatest effect on the antioxidant capacity (FRAP and ABTS respectively). It was observed that pectin, polyphenol, chlorogenic acid, flavonoid and anthocyanin concentrations tended to increase after a single application of Kelpak in a dose of $2 \mathrm{dm}^{3} \mathrm{ha}^{-1}$. A long-term storage period had a stronger effect on the increase in the oxidation potential than on the antioxidant capacity FRAP value.
\end{abstract}

Keywords: polyphenols; chlorogenic acid; flavonoids; anthocyanins; pectins

\section{Introduction}

Carrot (Daucus carota L.), due to its high yield, good storage stability and year-round availability, is a horticultural plant of great economic importance [1]. Its roots are characterized by a high nutrient content and a high concentration of bioactive ingredients. The color of the carrot roots is a key physical characteristic for commercial classification and purchasing decisions [2]. It also provides a basis for the quantification of freshness, which is particularly important for raw vegetable material intended for direct consumption. The color of carrot storage roots is, therefore, a quality criterion not only for the buyer, but also for the seller [2,3]. The change in the color of vegetable roots after harvest is closely related to the degradation of compounds responsible for browning processes, and is the effect of the ageing process. Polyphenols are natural compounds responsible for granary root darkening. They are classified as hydrophilic antioxidants and represent the largest and most diverse group in terms of structure and properties [4]. Carrots is rich in polyphenolic substances, which makes its roots susceptible to enzymatic browning. Enzymatic browning depends on the physiological state of the vegetable, the activity of polyphenolic oxidases (PPO), as well as the presence of polyphenols, 
mainly catechins, chlorogenic and coffee acids, which are most reactive [5]. The browning process occurs as a consequence of the reaction of polyphenolic compounds with PPO in the presence of oxygen, usually initiated by the enzymatic oxidation of monophenols into o-diphenols and o-diphenols into quinones. These compounds undergo further nonenzymatic polymerization, leading to the formation of dark colored, nonsoluble pigments such as melanins [6]. Polyphenols can inhibit or intensify the effect of numerous enzymes and activate antioxidants [7]. A reduction in enzymatic browning can be achieved by various methods, but unfortunately, not all polyphenols can be applied to fresh raw material intended for the market.

The use of biostimulants, effective microorganisms (EM), bacterial vaccines and algae extracts is gaining popularity, especially in sustainable agriculture. These preparations trigger numerous physiological processes stimulating plant growth and tolerance to abiotic stress while reducing mineral fertilizers $[8,9]$. The degree of their effect in vegetable roots depends on the dose and the frequency of application, among other factors [10,11]. According to a previous study [12-14], the single application of Kelpak seaweed biostimulant was favorable for carrot root yield and quality (increased total sugars, reducing sugars, vitamin $C$ and nitrates).

However, the concentration variability of bioactive compounds responsible for carrot root darkening processes resulting from the application of modern cultivation technologies with biostimulants and the influence on these parameters of long-term storage have not yet been studied. Therefore, research was carried out to assess the effect of biostimulants used in carrot cultivation and the long-term storage on the content of antioxidant compounds which determine enzymatic browning processes in roots.

\section{Materials and Methods}

\subsection{Field Experiment}

The study was based on field experiments performed in Poland $\left(53^{\circ} 13^{\prime} \mathrm{N} ; 17^{\circ} 51^{\prime} \mathrm{E}\right)$, conducted in 2009, 2010, and 2011 on a typical Alfisol (USDA). The soil used in the experiment was a Luvisol (LV) with a fine sandy loam texture. The topsoil was characterized by a low or medium content of potassium (95-150 mg kg-1) and a high content of available phosphorus (190-210 mg kg-1) (determined with Egner-Riehm method), very low content of magnesium $\left(<20.0 \mathrm{mg} \mathrm{kg}^{-1}\right)$ (determined with Schatschabel method) and slightly acid reaction ( $\mathrm{pH}$ in $1 \mathrm{M} \mathrm{KCL}$ 5.7-6.1). The contents of total nitrogen $\left(0.69-0.75 \mathrm{~g} \mathrm{~kg}^{-1}\right)$ and organic carbon $\left(7.55-7.80 \mathrm{~g} \mathrm{~kg}^{-1}\right)$ in the soil were relatively low $[12,13]$. Of the research years, 2011 was most favorable. The 2010 year, with a long-lasting drought in June, was less favorable for carrot growth, while 2009, with a severe drought in August, was the least favorable. The mean air temperatures were: in $2009-14.0^{\circ} \mathrm{C}$; in $2010-14.7^{\circ} \mathrm{C}$; and in $2011-15.2^{\circ} \mathrm{C}$. The total rainfall was $329.0 \mathrm{~mm}, 477.3 \mathrm{~mm}$, and $389.9 \mathrm{~mm}$, in 2009, 2010 and 2011, respectively [12]. Sowing was performed on the 1st, 3nd and 5th April, and a harvest was made on the 21st, 25th and 29th September in 2009, 2010 and 2011, respectively. The vegetation periods in those years were 173,175 and 177 days, respectively. The study was performed in a single-factorial design with the 'Karotan' carrot (Daucus carota L.) cultivar. In the experiment, the macroalga biostimulant Kelpak and synthetic Asahi SL were used in three growing seasons. The Kelpak biostimulant is produced from Ecklonia maxima Osbeck, from the division of brown algae (Phaeophyta), harvested in the south of Africa. The biostimulant contains auxins and cytokinins ( 11 and $0.031 \mathrm{mg} \mathrm{dm}^{-3}$, respectively), alginates, amino acids, brassinosteroids, as well as small amounts of macro- and microelements $(0.09 \% \mathrm{~N} ; 90.7 \mathrm{P}$, 7163.3 K, 190.4 Ca, 337.2 Mg, 1623.7 Na 17.3 Mn, 40.7 Fe, 13.5 Cu, 17.0 Zn, 33.0 B mg kg-1 fresh weight; $[9,15]$. The Asahi SL synthetic preparation includes $0.3 \%$ para-nitrophenol (PNP) sodium salt, $0.2 \%$ sodium ortho-nitrophenol (ONP) sodium salt, and $0.1 \%$-nitroguaiacol sodium salt (5NG). The biostimulant Asahi SL was included in the current study for comparison with the effect of natural algae extract Kelpak. Biostimulants were used in the form of foliar applications. Kelpak was dissolved in $300 \mathrm{dm}^{3}$ of water ha ${ }^{-1}$ for each treatment (the most popular dose in foliar application of pesticides, 
fertilizers or biostimulants) and foliar applied at the total rate of 2, 3, 4, 5, 6, and $7 \mathrm{dm}^{3} \mathrm{ha}^{-1}$ in the growing season (Table 1). Asahi was applied twice in doses of $0.5 \mathrm{dm}^{3}$ per ha $\mathrm{h}^{-1}$ after dissolving in $500 \mathrm{dm}^{3}$ of water in each treatment (according to the manufacturer's recommendation). Tillage, sowing, fertilization, plant protection, and storage processing were performed following the method described by Szczepanek et al. [12] and with the methods of integrated carrot production [16], on plots of $13 \mathrm{~m}^{2}$, in four replications. Usually, there was no significant interaction between year and the experimental factor; therefore, only the average values from the three years of the study are presented.

Table 1. Experimental treatments.

\begin{tabular}{ccc}
\hline Biostimulant & $\begin{array}{c}\text { Rates } \\
\left(\mathbf{d m}^{\mathbf{3}} \mathbf{h} \mathbf{a}^{\mathbf{- 1}} \mathbf{)}\right.\end{array}$ & Date of Application \\
\hline Control & - & - \\
Kelpak 1 & 3 & in 4-leaf stage (BBCH 14) \\
Kelpak 2 & 2 & in 4-leaf stage (BBCH 14) \\
\hline Kelpak 3 & $3+2$ & in 4-leaf stage (BBCH 14) + 14 days after 1st treatment \\
Kelpak 4 & $2+2$ & in 4-leaf stage (BBCH 14) + 14 days after 1st treatment + 28 days \\
Kelpak 5 & $3+2+2$ & after 1st treatment \\
Kelpak 6 & $2+2+2$ & in 4-leaf stage (BBCH 14) + 28 days after 1st treatment \\
\hline Kelpak 7 & $3+2$ & in 4-leaf stage (BBCH 14) + 14 days after 1st treatment \\
Kelpak 8 & $2+2$ &
\end{tabular}

\subsection{Storage Conditions}

Carrot roots were harvested at full physiological maturity. The qualitative characteristics were analyzed directly after the harvest and after six months of storage. The samples of carrot roots $(10 \mathrm{~kg}$ from each plot) were stored in chambers in normal atmosphere, at a constant temperature of $+1^{\circ} \mathrm{C}$ and a relative air humidity of $95 \%$.

\subsection{Sample Preparation}

The laboratory samples of carrot roots $(1 \mathrm{~kg})$ were washed carefully with distilled water, and then cut and well mixed. Next, the samples were frozen and kept at $-20^{\circ} \mathrm{C}$ in a freezer (Whirlpool AFG 6402 E-B, Italy). For laboratory analyses, the frozen material was freeze-dried (Alpha model 1-4 LSC, Germany). The plant material was lyophilized to constant weight with a moisture content below $2 \%$. Dried carrot roots were milled to a fine powder of particle size $0.3-0.5 \mathrm{~mm}$ using an Ultra-Centrifuge Retsch mill ZM 100 (Retsch, Germany). The milled samples were kept in air-tight containers with no access to light in desiccators until further analyses.

Preparation of Extracts for Measurement of Polyphenolic Compounds and Antioxidant Capacity FRAP

The lyophilized sample $(1 \mathrm{~g})$ was put into a $10 \mathrm{~mL}$ vial; then, $3 \mathrm{~mL}$ of methanol was added and the vial was shaken for $20 \mathrm{~min}$ in a laboratory shaker (IKA KS 130 BASIC, IKA, Warsaw, Poland). The mixture was then centrifuged for $1 \mathrm{~min}$ at $3000 \mathrm{rpm}$ at $4{ }^{\circ} \mathrm{C}$ using the Rotina $420 \mathrm{R}$ centrifuge (Hettich, Tuttlingen, Germany). The solution was decanted into a $10 \mathrm{~mL}$ graduated flask. The procedure was repeated three times for each sample; the combined solutions were made up to the full volume, i.e., $10 \mathrm{~mL}$, with methanol. The material was frozen in the Whirlpool AFG $6402 \mathrm{E}-\mathrm{B}$ freezer (Comerio, Italy). The aforementioned procedure was performed following the method proposed by Keutgen and Pawelzik [17]. 


\subsection{Isolation and Determination of Pectin Fractions}

Hydrochloric acid is considered the optimal solvent to extract pectin [18]. Pectin was extracted using $0.1 \mathrm{~N} \mathrm{HCl}$ at extraction temperature $\left(90^{\circ} \mathrm{C}\right)$, extraction duration $(60 \mathrm{~min})$, and $\mathrm{pH}(2.0)$. The $\mathrm{pH}$ of the solution was adjusted with $\mathrm{NaOH}$ and $\mathrm{HCl}$. Each sample (30 parts of the extraction solvent and 1 part of carrot root powder) was heated in a water bath. The heated extractant was filtered through a cheesecloth and pressed to recover the extract. Pectin precipitation was obtained with $95-98 \%$ ethanol (1 part of extractant and 2 parts of ethanol) and stored at room temperature overnight. The precipitated pectin was filtered through Whatman filter No. 1 and rinsed with $75 \%(v / v)$ ethanol, $85 \%(v / v)$ ethanol, and absolute ethanol to remove the soluble impurities. Pectin was then desiccated at $60^{\circ} \mathrm{C}$ for $24 \mathrm{~h}$ in a cabinet drier (WAMED, model SUB-100, Poland). The pectin content was calculated as follows:

$$
\text { Pectin content }\left[\frac{g}{\mathrm{~kg}}\right]=\frac{\text { weight of dried pectin }[g]}{\text { weight freeze }- \text { dried powder taken for extraction }[g]} \times 100
$$

\subsection{Determination of Total Polyphenolic Compounds}

Prepared and stored extracts were taken from the freezer and left at $21^{\circ} \mathrm{C}$. The volume of $0.3 \mathrm{~mL}$ of the extract was collected in a glass tube and $0.7 \mathrm{~mL}$ of distilled water was added. Next, $5 \mathrm{~mL}$ of Folin-Ciocalteu $(0.2 \mathrm{~N})$ reagent was added and after three minutes, $4 \mathrm{~mL}$ of sodium carbonate solution $\left(75 \mathrm{~g} \mathrm{dm}^{-3}\right)$ (POCH S.A., Gliwice, Poland) was added. Samples were incubated for $1.5 \mathrm{~h}$ at room temperature $\left(21^{\circ} \mathrm{C}\right)$ with no access to light. A thick cuvette of size $1 \mathrm{~cm} \times 1 \mathrm{~cm}$ was filled and absorbance at a wavelength of $736 \mathrm{~nm}$ was measured. The absorbance was measured using Shimadzu UV-1800 Vis 25 spectrophotometer (Kyoto, Japan). Total phenolic content was calculated from the calibration curve prepared for gallic acid equivalents (GAE). The aforementioned procedure was performed in compliance with the modified method proposed by Keutgen and Pawelzik [17]. The procedure was repeated five times for each temperature for short-time exposure and each sample.

\subsection{Determination of Chlorogenic Acid}

The content of chlorogenic acid was determined with the colorimetrical method of Griffiths et al. [19], according to sodium nitrate procedure. Freeze-dried carrot powder (200 mg) was vortexed with $2 \mathrm{~mL}$ of urea $(0.17 \mathrm{M})$ and acetic acid $(0.10 \mathrm{M})$. Next, $1 \mathrm{~mL}$ of sodium nitrite $(0.14 \mathrm{M})$ was added, followed by $1 \mathrm{~mL}$ of sodium hydroxide $(0.5 \mathrm{M})$ after incubation at room temperature for two minutes. The obtained suspension was centrifuged (Hettina Zentrifugen, Rotina 420 R, Germany) at $2250 \mathrm{~g}$ for $10 \mathrm{~min}$. An aliquot of the supernatant was taken, and the absorbance of the formed cherry-red complex was read at $510 \mathrm{~nm}$ (UV-1800, UV Spectrophotometer System, Japan). A standard curve was prepared using different concentrations of chlorogenic acid and the results were expressed as $\mathrm{mg}$ of chlorogenic acid per $1 \mathrm{~kg}$ of fresh carrot roots.

\subsection{Determination of Flavonoids}

Methanolic solutions of quercetin in the range of $4.0-12.0 \mu \mathrm{g} \cdot \mathrm{ml}^{-1}$ were used as references. To $2 \mathrm{~mL}$ of each reference solution, $20 \mathrm{~mL}$ of methanol and $1 \mathrm{~mL}$ of $5 \%(w / v)$ methanolic solution of $\mathrm{AlCl}_{3}$ were added and marked-up to a final volume of $50 \mathrm{~mL}$ with methanol at $20^{\circ} \mathrm{C}$. After $30 \mathrm{~min}$, the absorbance was measured at $425 \mathrm{~nm}$ using a Shimadzu-UV-1800 (System, Japan) spectrophotometer. The same protocol was used to analyze the crude extract against the blank, i.e., $5 \%(w / v) \mathrm{AlCl}_{3}$ [20]. The contents were expressed as milligram equivalents of quercetin per $\mathrm{ml}$ of the extracts.

\subsection{Determination of Total Anthocyanins}

Total anthocyanin content was measured using the method by Cheng and Breen [21]. The absorbance of the extract from $1 \mathrm{~g}$ of carrot skin, was measured at 510 and $700 \mathrm{~nm}$ in buffers at $\mathrm{pH} 1.0$ (hydrochloric acid-potassium chloride, $0.2 \mathrm{M}$ ) and $\mathrm{pH} 4.5$ (acetate acid-sodium 
acetate, $1 \mathrm{M}$ ). The anthocyanin content was calculated using a molar extinction coefficient of 29,600 (cyanidin-3-glucoside) and absorbance of $A=[A 510-A 700) p H 1.0-(A 510-A 700) p H 4.5$. The results were expressed as mg cyanidin-3-glucoside equivalents per $\mathrm{kg}$ of fresh weight (FW).

\subsection{Determination of Discoloration Potential}

The analysis was carried out using the colorimetric method [22]. For the homogenization method, equal portions of $25 \mathrm{~g}$ of each of the apical and basal ends of six tubers were homogenized in a laboratory mixer (BOSCH, model MSM67170, BSH GmbH Germany) for $30 \mathrm{~s}$ in a $25 \mathrm{~mL} 0.02 \mathrm{M}$ phosphate buffer. The homogenate was left to oxidize for $24 \mathrm{~h}$. The absorbance was measured at $475 \mathrm{~nm}$ with an SHIMADZU UV-1800, UV-Vis spectral photometer system (Japan). The samples were diluted at a 1:3 ratio before the photometric measurements. The results are the mean of three measurements and are presented as Absorbance Units (AU475) at $475 \mathrm{~nm}$.

\subsection{Assessment of the Antioxidant Capacity FRAP}

The antioxidant capacity was evaluated with the FRAP method using the protocol developed by Benzie and Strein [23]. A FRAP working solution was prepared before the assay. Two hundred and fifty milliliters of acetate buffer with a pH of 3.6, $25 \mathrm{~mL}$ of the TPTZ solution (2,4,6-Tri(2-pyridyl)-s-triazine (10 $\mathrm{mM}$ in $40 \mathrm{mM} \mathrm{HCl}$ ) and $25 \mathrm{~mL}$ of iron (III) chloride hexahydrate solution $(20 \mathrm{mM})$ were mixed. The solution was incubated at $37^{\circ} \mathrm{C}$ and assays were then performed. Six milliliters of the FRAP solution were added to $200 \mu \mathrm{L}$ of the sample and $600 \mu \mathrm{L}$ of $\mathrm{H}_{2} \mathrm{O}$. Four minutes after the addition of the sample, absorbance was measured at $593 \mathrm{~nm}$. Based on the conducted measurements, a dependence curve of the absorbance value on the material concentration was plotted. Based on the curve, the absorbance value was determined at a concentration equal to the mean of the dilutions used, and the antioxidant capacity was calculated at the same absorbance value based on the standard curve determined for $\mathrm{Fe}^{2}$ ions. To remove solid parts, the samples before the assays were centrifuged for five minutes with a Rotina 420R centrifuge (Hettich, Germany) at 3000 revs. $\mathrm{min}^{-1}$. All assays were performed in three replications.

\subsection{Determination of the Antioxidant Capacity by the ABTS ${ }^{+\bullet}$ Cation Radical Method}

The antioxidant capacity was determined by the $\mathrm{ABTS}^{+}{ }^{\bullet}$ cation radical [2,2'-azinobis(3-ethylbenzothiazoline-6-sulphonate] method according to Re et al. [24]. The ABTS ${ }^{+}$ cation radical was chemically generated using the incubation of a mixture of $7 \mathrm{mM}$ ABTS solution (Sigma Aldrich) and $2.45 \mathrm{mM} \mathrm{K} \mathrm{S}_{2} \mathrm{O}_{8}$ solution (POCH Gliwice), mixed in a ratio of 1:0.5, in a dark room for $12 \mathrm{~h}$. Before the measurement, the $\mathrm{ABTS}^{+\bullet}$ cation radical solution was diluted with a PBS phosphate buffer (POCH Gliwice) with a $\mathrm{pH}$ of 7.4 , to obtain the absorbance value of $0.70( \pm 0.020)$ at a wavelength of $734 \mathrm{~nm}$. For the measurement, four different sample dilutions were prepared so that the reduction in cation radical absorbance was within the range of $20-80 \%$. The measurement was performed in the following manner: $50 \mu \mathrm{L}$ of the sample was added to $5 \mathrm{~mL}$ of diluted cation radical, shaken, and incubated in a water bath at $30^{\circ} \mathrm{C}$ for $6 \mathrm{~min}$. After that time, the absorbance was measured using a SHIMADZU UV-1800 spectrophotometer, UV-Vis Spectral Photometer System (Japan), at a wavelength of $734 \mathrm{~nm}$, against a phosphate buffer. The curve for the percentage relationship between the cation radical reduction and the sample concentration was then plotted. Based on the curve, the cation radical absorbance reduction was determined at a concentration equal to the mean of the dilutions used and the antioxidant capacity was calculated at the same percentage cation radical reduction based on the standard curve for Trolox (Sigma Aldrich). The results were expressed as Mm Trolox $\mathrm{kg}^{-1}$, after accounting for the dilution of samples.

\subsection{Statistical Analysis}

Field experiments were established in three successive years, 2009, 2010 and 2010, in a completely randomized design (CRD) with four replications. The root samples were taken just after harvest and 
storage for six months. The quality assessment of roots harvested in each year was performed just after harvest and after storage. The results were statistically analyzed, performing an analysis of variance (ANOVA) of data from each experiment and the synthesis from three years in the mixed model. In the case of significant differences, a Tukey post hoc test was employed with a significance level of $\alpha=0.05$. The correlation coefficients were calculated using Pearson's rank-order at $p<0.01$. Regression equations were calculated concerning the relationship between qualitative characteristics of carrot roots. All analyses were calculated using Statistica ${ }^{\circledR} 13.1$ software.

\section{Results and Discussion}

The tendency for roots to darken after harvest and after storage averaged 0.124 and $0.130 \mathrm{AU}_{(475) \text {, }}$ respectively (Table 2). According to the classification by Dean et al. [22] (Table 3), such roots can be considered as a raw material which is resistant to enzymatic darkening. Some authors $[3,25]$ have suggested that the enzymatic browning of vegetables, including carrots, is determined by mineral fertilization or the use of biostimulants. High nitrogen fertilization results in increased susceptibility to darkening processes [26]. However, the use of potassium and magnesium fertilizers protects plants against this process [27]. There is little research concerning the effect of biostimulant application on the tendency to darken. In a study carried out by Keutgen et al. [2,3], UGmax biostimulant was shown to lower the tendency of different carrot cultivars to darken. This research confirmed that the application of Kelpak and Asahi biostimulants reduces the tendency of roots to darken, both after harvest and after storage (Table 2). For the Kelpak seaweed biostimulant, the lowest discoloration potential was recorded after a single application of 2 or $3 \mathrm{dm}^{3}$ at the 4-leaf phase (Table 2). A similar reaction was caused by the application of Asahi, whereas the highest tendency to darken $(0.148 \mathrm{AU}(475))$ was observed in carrot roots in which no biostimulants were used.

During storage, the tendency of roots to darken increases as a result of intensified life processes [8]. In our studies after storage, an increase in the value of the oxidative potential was observed in relation to its value after harvest (Table 4). For the Asahi synthetic biostimulant, the increased oxidative potential after storage was higher than after the application of the Kelpak natural biostimulant.

Table 2. Discoloration potential, antioxidant capacity by the FRAP (ferric reducing antioxidant potential) and ABTS (radical-scavenging activity assays), pectin content depending on the application of biostimulants and storage (means from three years).

\begin{tabular}{|c|c|c|c|c|}
\hline Biostimulant & $\begin{array}{c}\text { Discoloration } \\
\text { Potential }\left[\mathrm{AU}_{475}\right]\end{array}$ & $\begin{array}{c}\text { FRAP [mM Fe } \\
\left.k^{2} g^{-1} \mathrm{FW}\right]\end{array}$ & $\begin{array}{c}\text { ABTS } \\
{\left[\mathrm{mM} \text { Trolox } \mathrm{kg}^{-1}\right]}\end{array}$ & $\begin{array}{l}\text { Pectins [g kg-1 } \\
\text { FW] }\end{array}$ \\
\hline & & \multicolumn{3}{|c|}{ After harvest } \\
\hline Control & $0.143 \pm 0.023 c$ & $1.66 \pm 0.05 a$ & $0.655 \pm 0.0124 \mathrm{a}$ & $10.37 \pm 0.39 a$ \\
\hline Kelpak 1 & $0.099 \pm 0.007 \mathrm{a}$ & $1.84 \pm 0.08 \mathrm{de}$ & $0.822 \pm 0.0212 b$ & $11.57 \pm 0.47 \mathrm{~cd}$ \\
\hline Kelpak 2 & $0.095 \pm 0.008 \mathrm{a}$ & $1.87 \pm 0.07 \mathrm{e}$ & $0.921 \pm 0.0242 c$ & $11.67 \pm 0.45 \mathrm{~d}$ \\
\hline Kelpak 3 & $0.131 \pm 0.020 \mathrm{~b}$ & $1.72 \pm 0.08 \mathrm{a}-\mathrm{d}$ & $0.666 \pm 0.0341 \mathrm{a}$ & $10.75 \pm 0.41 \mathrm{ab}$ \\
\hline Kelpak 4 & $0.135 \pm 0.025 b$ & $1.69 \pm 0.06 \mathrm{a}-\mathrm{d}$ & $0.651 \pm 0.0164 \mathrm{a}$ & $10.65 \pm 0.38 \mathrm{ab}$ \\
\hline Kelpak 5 & $0.134 \pm 0.021 b$ & $1.74 \pm 0.08 \mathrm{ab}$ & $0.659 \pm 0.0235 \mathrm{a}$ & $10.89 \pm 0.37 \mathrm{a}-\mathrm{c}$ \\
\hline Kelpak 6 & $0.135 \pm 0.019 b$ & $1.76 \pm 0.08 \mathrm{a}-\mathrm{e}$ & $0.802 \pm 0.03144 b$ & $11.27 \pm 0.36 b-d$ \\
\hline Kelpak 7 & $0.135 \pm 0.022 b$ & $1.78 \pm 0.09 \mathrm{a}-\mathrm{e}$ & $0.801 \pm 0.04121 b$ & $11.06 \pm 0.37 \mathrm{a}-\mathrm{d}$ \\
\hline Kelpak 8 & $0.126 \pm 0.023 \mathrm{ab}$ & $1.81 \pm 0.07 \mathrm{~b}-\mathrm{e}$ & $0.831 \pm 0.0333 b$ & $11.47 \pm 0.36 \mathrm{~cd}$ \\
\hline Asahi & $0.110 \pm 0.002 \mathrm{a}$ & $1.84 \pm 0.07 \mathrm{c}-\mathrm{e}$ & $0.829 \pm 0.0123 b$ & $10.45 \pm 0.49 \mathrm{a}$ \\
\hline Mean Kelpak & 0.124 & 1.78 & 0.769 & 11.17 \\
\hline Mean total & 0.124 & 1.77 & 0.764 & 11.01 \\
\hline
\end{tabular}


Table 2. Cont.

\begin{tabular}{|c|c|c|c|c|}
\hline Biostimulant & $\begin{array}{c}\text { Discoloration } \\
\text { Potential [AU } \mathrm{AU}_{475} \text { ] }\end{array}$ & $\begin{array}{c}\text { FRAP [mM Fe } \\
\left.\mathrm{kg}^{-1} \mathrm{FW}\right]\end{array}$ & $\begin{array}{c}\text { ABTS } \\
{\left[\mathrm{mM} \text { Trolox } \mathrm{kg}^{-1}\right]}\end{array}$ & $\begin{array}{l}\text { Pectins }\left[\mathrm{g} \mathrm{kg}^{-1}\right. \\
\text { FW] }\end{array}$ \\
\hline & & \multicolumn{3}{|c|}{ After storage } \\
\hline Control & $0.148 \pm 0.029 c$ & $1.73 \pm 0.07 \mathrm{a}$ & $0.666 \pm 0.02852 a$ & $10.03 \pm 0.51 \mathrm{a}$ \\
\hline Kelpak 1 & $0.109 \pm 0.003 a$ & $1.92 \pm 0.08 \mathrm{bc}$ & $0.934 \pm 0.0324 \mathrm{~d}$ & $11.35 \pm 0.72 b$ \\
\hline Kelpak 2 & $0.106 \pm 0.093 a$ & $1.94 \pm 0.06 \mathrm{c}$ & $0.930+ \pm 0.0124 \mathrm{~d}$ & $11.45 \pm 0.74 \mathrm{~b}$ \\
\hline Kelpak 3 & $0.133 \pm 0.024 b$ & $1.79 \pm 0.08 \mathrm{ab}$ & $0.721 \pm 0.0341 b c$ & $10.52 \pm 0.66 \mathrm{ab}$ \\
\hline Kelpak 4 & $0.140 \pm 0.030 \mathrm{~b}$ & $1.76 \pm 0.08 \mathrm{ab}$ & $0.674 \pm 0.01658 \mathrm{ab}$ & $10.24 \pm 0.47 \mathrm{ab}$ \\
\hline Kelpak 5 & $0.139 \pm 0.026 b$ & $1.81 \pm 0.10 \mathrm{a}-\mathrm{c}$ & $0.704 \pm 0.0328 \mathrm{ab}$ & $10.69 \pm 0.59 \mathrm{ab}$ \\
\hline Kelpak 6 & $0.139 \pm 0.019 b$ & $1.84 \pm 0.09 \mathrm{a}-\mathrm{c}$ & $0.744 \pm 0.0328 c$ & $11.13 \pm 0.75 \mathrm{ab}$ \\
\hline Kelpak 7 & $0.138 \pm 0.023 b$ & $1.85 \pm 0.10 \mathrm{a}-\mathrm{c}$ & $0.738 \pm 0.01899 c$ & $10.87 \pm 0.67 \mathrm{ab}$ \\
\hline Kelpak 8 & $0.130 \pm 0.026 \mathrm{ab}$ & $1.88 \pm 0.09 \mathrm{bc}$ & $0.754 \pm 0.0234 \mathrm{c}$ & $11.15 \pm 0.76 \mathrm{ab}$ \\
\hline Asahi & $0.118 \pm 0.055 \mathrm{a}$ & $1.91 \pm 0.07 \mathrm{bc}$ & $0.928 \pm 0.03777 d$ & $10.17 \pm 0.62 \mathrm{a}$ \\
\hline Mean Kelpak & 0.129 & 1.85 & 0.775 & 10.93 \\
\hline Mean total & 0.130 & 1.84 & 0.779 & 10.76 \\
\hline
\end{tabular}

a, b, c, d, e-Means sharing the same letter in column are not significantly different $(p<0.05)$.

Table 3. Classes of susceptibility to oxidation darkening processes, according to Dean et al. [22].

\begin{tabular}{cc}
\hline Susceptibility Classes & Colorimetric Method $\left[\mathrm{AU}_{\mathbf{4 7 5}}\right]$ \\
\hline Resistant to darkening processes & $0-0.20$ \\
Moderately resistant to darkening processes & $0.21-0.40$ \\
Moderately susceptible to darkening processes & $0.41-0.60$ \\
Susceptible to darkening processes & $0.61-0.80$ \\
Very susceptible to darkening processes & $>0.80$ \\
\hline
\end{tabular}

Table 4. Changes in the quality parameters of carrots after six months of storage as compared to the values after harvest [\%].

\begin{tabular}{ccccccccc}
\hline Biostimulant & $\begin{array}{c}\text { Discoloration } \\
\text { Potential }\end{array}$ & FRAP ${ }^{++}$ & ABTS ${ }^{+\dagger}$ & Pectin & Polyphenols & $\begin{array}{c}\text { Chlorogenic } \\
\text { Acid }\end{array}$ & Flavonoids Anthocyanins \\
\hline Control & $+3.5^{*}$ & +4.2 & +1.7 & -3.3 & +4.5 & +4.8 & +5.5 & -3.3 \\
Asahi & +7.3 & +3.8 & +11.9 & -2.7 & +4.9 & +4.1 & +5.4 & -4.0 \\
Kelpak $^{\dagger}$ & +4.6 & +3.9 & -2.0 & -2.3 & +4.8 & +3.3 & +5.2 & -3.4 \\
\hline
\end{tabular}

* Calculation: The initial (after harvest) and final (after storage) values of quality characteristics are presented in Tables 2 and 5, ${ }^{+}$Mean for all Kelpak treatments, ${ }^{++}$FRAP-ferric reducing antioxidant potential; ABTS- radical-scavenging activity assays.

The FRAP and ABTS (antioxidant capacity) values of the tested 'Karotan' cultivar averaged 1.77; 0.764 and $1.84 ; 0.769 \mathrm{mM} \mathrm{Fe}^{2} \mathrm{~kg}^{-1}$ after harvest and storage, respectively (Table 2). Koley et al. [28] tested 16 carrot cultivars with a FRAP test and determined the hydrophilic antioxidant activity expressed in $\mu \mathrm{M}$ Trolox $\mathrm{g}^{-1}$ from 0.61 for Pusa Yamdagni cultivar to 51.93 for Pusa Asita cultivar. Sun et al. [29] found the antioxidant capacity measured with the use of the ABTS assay for orange carrots amounted to $20.2 \mathrm{mM}$ Trolox $\mathrm{kg}^{-1}$ of dry matter and Singh et al. [30] recorded $3.07 \mathrm{mM}$ Trolox $\mathrm{kg}^{-1}$. A significant increase in the FRAP antioxidant potential as compared to the control was found after a single application of the Kelpak seaweed biostimulant in the amount of 2 or $3 \mathrm{~L}$ at the 4-leaf phase and after sequential application of $2 \mathrm{dm}^{3}$ at the 4-leaf phase $+2 \mathrm{dm}^{3}$ after 28 days (Table 2). For ABTS oxidation potential, the beneficial effect was additionally demonstrated after the sequential application of $3 \mathrm{dm}^{3}$ at the 4-leaf phase $+2 \mathrm{dm}^{3}$ after 14 days (after storage) and 2 or $3 \mathrm{dm}^{3}$ at the 4-leaf phase $+2 \mathrm{dm}^{3}$ after 14 days (after harvest). Similarly, Keutgen et al. [25], using soil conditioner (UGmax) in the cultivation of four carrot cultivars, demonstrated its positive effect on the antioxidant capacity of the roots. The authors obtained the highest increase in FRAP antioxidant capacity for cultivars with the orange root, as compared to cultivars with yellow and purple roots. This increase can be 
attributed to two possible mechanisms: the activation of key enzymes involved in the homeostasis of cellular antioxidants, and an increase in assimilation of the macro- and micro- elements involved in the synthesis of amino acids $[8,26]$.

Table 5. Polyphenols, chlorogenic acid, flavonoids and anthocyanins contents depending on the application of biostimulants and storage (means from three years).

\begin{tabular}{|c|c|c|c|c|}
\hline Biostimulant & $\begin{array}{l}\text { Polyphenols [mg } \\
\text { kg }^{-1} \text { FW] }\end{array}$ & $\begin{array}{l}\text { Chlorogenic Acid } \\
{\left[\mathrm{mg} \mathrm{kg}^{-1} \text { FW] }\right.}\end{array}$ & $\begin{array}{l}\text { Flavonoids [mg } \\
\left.\mathrm{kg}^{-1} \mathrm{FW}\right]\end{array}$ & $\begin{array}{c}\text { Anthocyanin Pigments } \\
{\left[\mathrm{mg} \mathrm{kg}^{-1} \mathrm{FW}\right]}\end{array}$ \\
\hline & \multicolumn{4}{|c|}{ After harvest } \\
\hline Control & $260.8 \pm 6.8 \mathrm{a}$ & $169.9 \pm 4.0 \mathrm{a}$ & $21.9 \pm 4.0 \mathrm{a}$ & $4.45 \pm 0.08 \mathrm{a}$ \\
\hline Kelpak 1 & $276.9 \pm 6.1 \mathrm{~cd}$ & $182.6 \pm 1.0 \mathrm{c}-\mathrm{f}$ & $23.2 \pm 2.9$ ef & $4.67 \pm 0.03 c-e$ \\
\hline Kelpak 2 & $277.2 \pm 6.1 \mathrm{~d}$ & $188.0 \pm 1.3 \mathrm{f}$ & $23.6 \pm 3.9 \mathrm{f}$ & $4.87 \pm 0.04 \mathrm{~g}$ \\
\hline Kelpak 3 & $268.3 \pm 2.8 \mathrm{~b}$ & $178.2 \pm 1.7 \mathrm{~b}-\mathrm{d}$ & $22.7 \pm 1.9 \mathrm{~b}-\mathrm{d}$ & $4.62 \pm 0.04 \mathrm{~cd}$ \\
\hline Kelpak 4 & $268.2 \pm 2.8 \mathrm{~b}$ & $175.4 \pm 4.9 \mathrm{bc}$ & $22.5 \pm 1.6 b c$ & $4.53 \pm 0.04 b c$ \\
\hline Kelpak 5 & $268.6 \pm 2.8 \mathrm{ab}$ & $179.8 \pm 2.7 \mathrm{~b}-\mathrm{e}$ & $22.8 \pm 2.2 \mathrm{~b}-\mathrm{e}$ & $4.68 \pm 0.07 c-f$ \\
\hline Kelpak 6 & $270.0 \pm 2.4 \mathrm{bc}$ & $184.0 \pm 4.7 \mathrm{~d}-\mathrm{f}$ & $23.0 \pm 1.1 \mathrm{c}-\mathrm{e}$ & $4.74 \pm 0.04$ ef \\
\hline Kelpak 7 & $269.3 \pm 1.4 b$ & $182.4 \pm 3.6 \mathrm{c}-\mathrm{f}$ & $22.9 \pm 1.7 \mathrm{c}-\mathrm{e}$ & $4.72 \pm 0.05 \mathrm{~d}-\mathrm{f}$ \\
\hline Kelpak 8 & $270.2 \pm 7.1 \mathrm{bc}$ & $185.4 \pm 3.1 \mathrm{f}$ & $23.1 \pm 1.1 \mathrm{de}$ & $4.77 \pm 0.04 \mathrm{fg}$ \\
\hline Asahi & $267.5 \pm 6.3 \mathrm{ab}$ & $172.5 \pm 5.1 \mathrm{ab}$ & $22.4 \pm 1.3 \mathrm{ab}$ & $4.49 \pm 0.06 \mathrm{ab}$ \\
\hline Mean Kelpak & 271.1 & 182.0 & 23.0 & 4.70 \\
\hline \multirow[t]{2}{*}{ Mean total } & 269.7 & 179.8 & 22.8 & 4.65 \\
\hline & \multicolumn{4}{|c|}{ After storage } \\
\hline Control & $272.6 \pm 7.1 \mathrm{a}$ & $178.1 \pm 3.2 \mathrm{a}$ & $23.1 \pm 4.9 \mathrm{a}$ & $4.25 \pm 0.10 \mathrm{a}$ \\
\hline Kelpak 1 & $286.4 \pm 6.3 \mathrm{~cd}$ & $186.6 \pm 1.0 \mathrm{c}-\mathrm{e}$ & $24.6 \pm 3.1 \mathrm{de}$ & $4.56 \pm 0.02 c-f$ \\
\hline Kelpak 2 & $287.7 \pm 6.4 \mathrm{~d}$ & $194.7 \pm 1.7 \mathrm{~g}$ & $24.8 \pm 3.8 \mathrm{e}$ & $4.70 \pm 0.03 \mathrm{f}$ \\
\hline Kelpak 3 & $282.5 \pm 3.0 \mathrm{~b}$ & $184.8 \pm 1.8 \mathrm{~cd}$ & $23.9 \pm 2.1 b c$ & $4.45 \pm 0.04 \mathrm{~b}-\mathrm{d}$ \\
\hline Kelpak 4 & $281.4 \pm 2.9 \mathrm{~b}$ & $181.3 \pm 1.8 \mathrm{bc}$ & $23.7 \pm 3.4 b c$ & $4.39 \pm 0.12 b c$ \\
\hline Kelpak 5 & $283.8 \pm 2.9 \mathrm{ab}$ & $187.2 \pm 2.8 \mathrm{c}-\mathrm{f}$ & $24.0 \pm 2.7 b c$ & $4.50 \pm 0.07 \mathrm{~b}-\mathrm{e}$ \\
\hline Kelpak 6 & $285.2 \pm 2.5 \mathrm{~b}$ & $189.7 \pm 1.6$ ef & $24.3 \pm 2.8 \mathrm{~cd}$ & $4.60 \pm 0.12 \mathrm{def}$ \\
\hline Kelpak 7 & $284.5 \pm 2.9 \mathrm{~b}$ & $188.7 \pm 1.9 \mathrm{~d}-\mathrm{f}$ & $24.2 \pm 2.9 \mathrm{~cd}$ & $4.56 \pm 0.09 c-f$ \\
\hline Kelpak 8 & $286.5 \pm 2.5 b c$ & $190.8 \pm 1.4 \mathrm{fg}$ & $24.3 \pm 2.0 \mathrm{c}-\mathrm{e}$ & $4.64 \pm 0.08$ ef \\
\hline Asahi & $280.6 \pm 2.5 \mathrm{ab}$ & $179.5 \pm 2.4 \mathrm{ab}$ & $23.6 \pm 3.1 \mathrm{ab}$ & $4.31 \pm 0.13 \mathrm{ab}$ \\
\hline Mean Kelpak & 282.4 & 188.0 & 24.2 & 4.55 \\
\hline Mean total & 280.9 & 186.2 & 24.0 & 4.50 \\
\hline
\end{tabular}

a, b, c, d, e, f, g-Means sharing the same letter in column are not significantly different $(p<0.05)$.

Pectin is a very important cell wall component which can directly affect the shape and size of the cell [31], giving it tensile strength [32]. In the current study, the pectin content of carrot roots after harvest and storage was particularly positively affected by the application of the Kelpak natural biostimulant in the amount of 2 or $3 \mathrm{dm}^{3}$ in the 4-leaf phase (Table 2). Several authors observed that the use of a biostimulant could activate the transduction signal pathways by inducing endogenous synthesis of phytohormones (i.e., effects similar to auxins and gibberellins), thus leading to the higher quality of the raw material $[8,33]$. In our research, the content of pectins was lower after storage than after harvest (Table 4). The application of biostimulants reduced the loss of pectin after storage (Table 4), while roots that contained more pectins after harvest also contained more pectins after storage (Table 2). Sra et al. [34] stored carrots for six months and recorded a decrease in the pectin content at a level similar to that of our research, yet the fastest decrease in concentration was recorded in the first three months of storage. According to Sra et al. [34] and Arscott [35], the pectin content in carrots decreases as a result of pectin degradation during storage.

The ingredients with a direct effect on carrot root darkening include bioactive compounds such as polyphenols, flavonoids and anthocyanin pigments [36]. Since these compounds are very sensitive to external factors, their content in roots can be significantly influenced by cultivation conditions $[4,37]$. An important indicator of the antioxidant activity in carrots is the polyphenol content in roots [38]. 
In the current study, total polyphenols in fresh carrot storage roots ranged from 260.8 to $276.9 \mathrm{mg} \mathrm{kg}^{-1}$ after harvest, and from 272.6 to $287.7 \mathrm{mg} \mathrm{kg}^{-1}$ after storage (Table 5). The application of the Kelpak demonstrated a mostly beneficial effect on the concentration of polyphenols in carrot roots after harvest (Table 6). The use of algae biostimulants to increasing the content of polyphenols in plants is widely reported in the literature [39]. Increased biosynthesis of protective compounds such as polyphenols contributes to the increased tolerance of plants to stress [40]. Such a reaction of plants may lead to an increase in yields, which has been shown in our experiment [12]. After the single application of Kelpak, carrot root yield was the highest and the roots had the highest concentration of polyphenols.

Table 6. Pearson's rank order correlation coefficients (r) for the quality characteristics of carrot roots $(p \leq 0.01)$.

\begin{tabular}{|c|c|c|c|c|c|c|c|}
\hline Characteristics & $\mathrm{DP}^{+}$ & $\underset{+}{\text { FRAP }}$ & $\underset{+}{\text { ABTS }}$ & Polyphenols & Flavonoids & $\begin{array}{l}\text { Chlorogenic } \\
\text { Acid }\end{array}$ & $\begin{array}{c}\text { Anthocyanin } \\
\text { Pigments }\end{array}$ \\
\hline & \multicolumn{7}{|c|}{ After harvest } \\
\hline Pectins & -0.503 & 0.569 & 0.702 & 0.749 & 0.910 & 0.926 & 0.811 \\
\hline DP & & n.s & n.s & n.s & n.s & -0.474 & -0.477 \\
\hline FRAP & & & 0.858 & 0.836 & 0.671 & 0.592 & n.s \\
\hline ABTS & & & & 0.719 & 0.729 & 0.711 & 0.603 \\
\hline Polyphenols & & & & & 0.848 & 0.727 & 0.543 \\
\hline Flavonoids & & & & & & 0.929 & 0.855 \\
\hline \multirow[t]{2}{*}{ Chlorogenic acid } & & & & & & & 0.936 \\
\hline & \multicolumn{7}{|c|}{ After storage } \\
\hline Pectins & n.s & n.s & 0.728 & 0.811 & 0.915 & 0.694 & 0.864 \\
\hline DP & & n.s & n.s & n.s & n.s & n.s & n.s \\
\hline FRAP & & & 0.695 & 0.697 & 0.522 & n.s & n.s \\
\hline ABTS & & & & 0.634 & 0.674 & 0.730 & 0.588 \\
\hline Polyphenols & & & & & 0.892 & 0.540 & 0.734 \\
\hline Flavonoids & & & & & & 0.803 & 0.938 \\
\hline Chlorogenic acid & & & & & & & 0.929 \\
\hline
\end{tabular}

In the current study, long-term storage increased the total polyphenol content in carrot roots (Table 4). This growth was similar after the application of Kelpak and Asahi biostimulants. Changes in the content of polyphenolic compounds due to storage time and temperature were reported by Keutgen et al. [25] and Ahmed et al. [41]. Surface injuries and other mechanical damage often occur during harvest and root preparation for storage. In response, plants can regulate their metabolism and activate their defense mechanisms to heal damaged tissue [42]. There are numerous phenylpropanoid compounds synthesized by triggering the activity of phenylalanine ammonia-lyase associated with a damage-induced stress defense [43].

One of the most important ingredients found in vegetables is chlorogenic acid [44], the concentration of which, according to Sharma et al. [45] represents $42 \%$ to $62 \%$ of all phenolic compounds. Depending on the carrot cultivar, the chlorogenic acid content varies between 15 and $1400 \mathrm{mg} \mathrm{kg}^{-1} \mathrm{FW}[46,47]$. In the current study, the chlorogenic acid content amounted to 180 and $186 \mathrm{mg} \mathrm{kg}^{-1} \mathrm{FW}$, on average, after harvest and after storage, respectively (Table 4). Each method of the Kelpak seaweed biostimulant application resulted in an increase in the chlorogenic acid content after harvest and after storage as compared to the control sample (Table 5). The response of the chlorogenic acid concentration to the application of biostimulants was similar to that of total polyphenolic compounds. The interdependence of these parameters is confirmed by highly significant $(p<0.01)$ correlation coefficients of chlorogenic acid and total polyphenols, both after harvest and after storage (Table 6). This relationship is probably caused by the fact that chlorogenic acid accounts for more than half of the polyphenolic compounds [26]. The current research demonstrated that the 
Kelpak and Asahi biostimulants used in carrot cultivation increased the chlorogenic acid content after storage on average by 3.3\% and 3.9\%, respectively (Table 4). Hager and Howart [43] also observed an increase in the chlorogenic acid content after the storage of carrot roots. As reported by Arscott and Tanumihardjo [35], the activity of the phenylalanine ammonia lyase enzyme (responsible for the synthesis of chlorogenic acid) increases during storage.

Flavonoids and their anthocyanic pigments comprise a group of polyphenols commonly occurring in vegetables [48]. The content of flavonoids and anthocyanins after harvest averaged 22.8 and $4.7 \mathrm{mg} \mathrm{kg}^{-1} \mathrm{FW}$, respectively (Table 5). Bahorun et al. [49] found that the total flavonoid content of carrots was $45 \mathrm{mg} \mathrm{kg}^{-1}$, while Ranjith et al. [50] recorded $24 \mathrm{mg} \mathrm{kg}^{-1}$. As provided by Lazcano et al. [51], Kammerer et al. [52] and Arscott and Tanumihardjo [35], the content of anthocyanin pigments is very wide, ranging from 0 to $3500 \mathrm{mg}$ FW. Their content is closely correlated with the color of the root, being the highest in purple carrot roots $[4,48]$. Out of the biostimulants used, only the Kelpak natural seaweed extract demonstrated a positive effect on flavonoids and anthocyanins both after harvest and after storage (Table 5). A clear trend to increase the concentration of these compounds after a single application of the preparation in the smallest dose of $2 \mathrm{dm}^{3} \mathrm{ha}^{-1}$ was observed. Furthermore, a significant $(p<0.01)$ correlation was observed between the content of these antioxidants, both after harvest and after storage, respectively (Table 6). Keutgen et al. [3] obtained a reduction in anthocyanin content after applying the UGmax biostimulant. The differences obtained may result from different operation of those biostimulants. UGmax is a preparation containing microorganisms designed to rebuild organic matter (humus in soil) and improve water retention, while Kelpak contains phytohormones directly affecting plant physiological processes.

In the current study, storage increased the content of flavonoids in carrot roots (Table 4). The rise in flavonoids during storage was also reported by other authors [53]. The greatest increase in flavonoids responsible for the bitter taste of carrots, such as naringenin, is observed during storage [50]. According to Christensen and Brandt [54], the group of compounds responsible for the bitter taste of carrots is synthesized in response to storage-induced stress. The current study showed a relatively small decrease in anthocyanin pigments after long-term storage (Table 4). This decrease is the result of the external factors, leading to pigment degradation processes. The negative influence of storage on the content of anthocyanin pigments was reported by Keutgen et al. [3]. The authors observed a $24 \%$ decrease in the content of anthocyanin pigments after storing 'Karotan' cultivar carrots for three months. However, Kidoń and Czapski [55] did not report any change in the content of anthocyanin pigments in carrot juices stored at low temperatures, while the increase in storage temperature caused their clear degradation. In our research study, a slightly greater loss of anthocyanin pigments was observed after the application of Asahi compared with the Kelpak natural biostimulant (Table 4).

The current study indicates that the value of discoloration potential depends on the concentration of polyphenols, flavonoids, anthocyanins and chlorogenic acid (Table 6). It was demonstrated that with a low value of one of these parameters and an increase in the value of the second parameter, discoloration potential decreased (Figure 1a-d). Moreover, we found that at a low concentration of flavonoids and an increase in total polyphenol concentration, the value of antioxidant potential (FRAP) in the roots increased (Figure 2a,b). Significant correlation coefficients confirm the relationship between FRAP and polyphenols or flavonoid contents in the roots (Table 6). Similar relationships between FRAP values were also reported by other researchers $[2,56]$. 


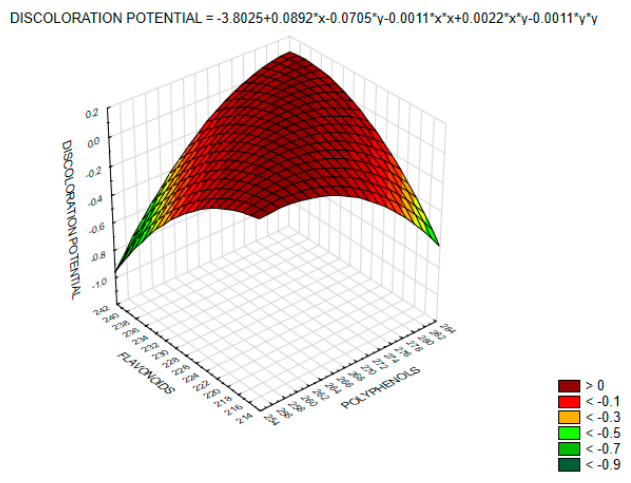

(a)

DISCOLORATION POTENTIAL $=-5.189+0.2043^{*} x-0.1953^{7} y-0.0009^{*} x^{*} x+0.0012^{*} x^{*} y-0.0003^{*} y^{*} y$

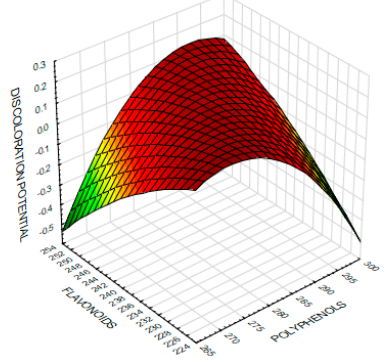

(c)
DISCOLORATION POTENTIAL $=-1.4806-0.026^{*} x+1.7391^{1} y+0.0004^{4} x^{*} x-0.023^{1} x^{x} y+0.2548^{7} y^{*} y$

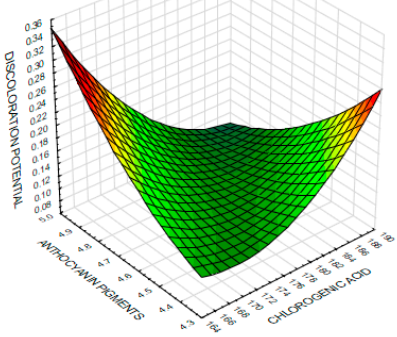

(b)

DISCOLORATION POTENTIAL $=0.5206+0.0323^{*} x-1.4652^{*} y+0.0001^{*} x^{*} x-0.0185^{*} x^{*} y+0.5494^{*} y^{*} y$

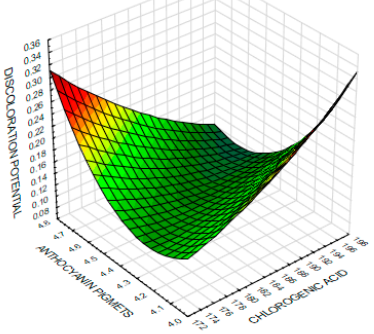

(d)

Figure 1. Discoloration potential depending on anthocyanin, polyphenol, flavonoid and chlorogenic acid contents after harvest $(\mathbf{a}, \mathbf{b})$, and after storage $(\mathbf{c}, \mathbf{d})$.

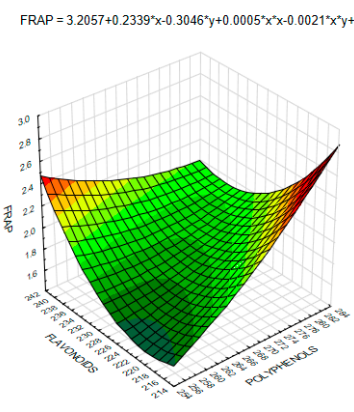

(a)

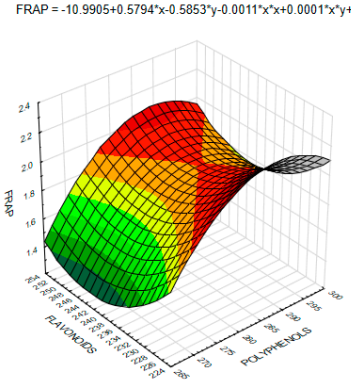

(c)

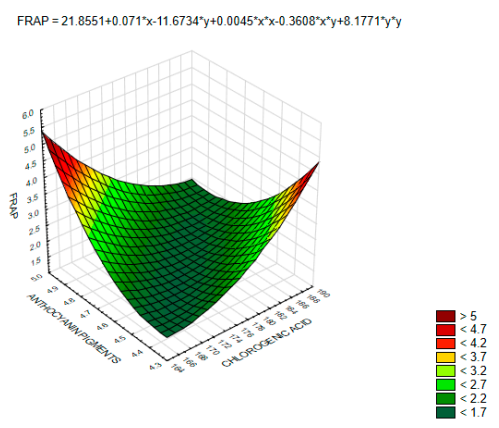

(b)

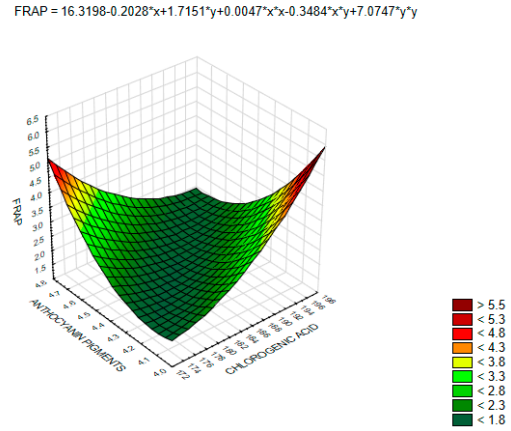

(d)

Figure 2. The antioxidant capacity (FRAP) depending on anthocyanin, polyphenol, flavonoid and chlorogenic acid contents after harvest $(\mathbf{a}, \mathbf{b})$, and after storage $(\mathbf{c}, \mathbf{d})$. 


\section{Conclusions}

The foliar application of biostimulants in carrot can be a good way to counteract darkening of the roots and to increase the content of bioactive compounds therein. It has been proven that biostimulants based on seaweed extract (Kelpak) and nitrophenols (Asahi) decreased the carrot root tendency to darken, both after harvest and after storage. The Kelpak seaweed extract proved to be the most effective in limiting oxidative darkening processes when applied in a single doses 2 or $3 \mathrm{dm}^{3} \mathrm{ha}^{-1}$ at the 4-leaf phase. Kelpak increased the concentration of bioactive compounds (polyphenol, chlorogenic acid, flavonoids and anthocyanin pigments), whereas no effect of the Asahi synthetic biostimulant was found. To reduce darkening and increase the antioxidant capacity and content of bioactive compounds in carrot roots after harvest and storage, Kalpak biostimulant should be used in a doses of 2 or $3 \mathrm{dm}^{3} \mathrm{ha}^{-1}$ at the 4-leaf phase.

Author Contributions: Conceptualization, M.S., J.P., E.W.; Methodology, M.S., J.P., E.W.; Formal Analysis, M.S., J.P., E.W., K.G.; Investigation, M.S., J.P., E.W., K.G.; Data Curation, M.S., J.P., E.W., K.G., Writing-Original Draft Preparation, M.S., J.P., E.W., K.G.; Writing—Review \& Editing, M.S., J.P., E.W., K.G.; Visualization, J.P., E.W., K.G.; Supervision, M.S., J.P., E.W.; Project Administration, M.S., J.P., E.W.; Funding Acquisition, M.S., J.P., E.W., K.G. All authors have read and agreed to the published version of the manuscript.

Funding: This research received no external funding.

Acknowledgments: The authors wish to thank the mediums and sitters who volunteered their time for this study. Publication was carried out with the use of instruments bought in the framework of the program "Development of Stage 2 of Regional Centre for Innovativeness" of the European Fund for Regional Development in the framework of the Regional Operation Programme of Kuyavian-Pomeranian for 2007-2013, Bydgoszcz, Poland.

Conflicts of Interest: The authors declare no conflict of interest.

\section{References}

1. Karklelienė, R.; Radzevičius, A.; Dambrauskienè, E.; Duchovskienė, L.; Bobinas, Č.; Kavaliauskaitė, D. Reproduction features of organically grown edible carrot cultivars (Daucus sativus Röhl.) in Lithuania. Agron. Res. 2009, 7, 305-310.

2. Keutgen, A.J.; Wszelaczyńska, E.; Pobereżny, J. Influence of cultivar and UGmax on antioxidative properties of carrot roots (Daucus carota L.) and their stability during freezing process. Environ. Prot. Nat. Resour. 2014, 25, 19-22. [CrossRef]

3. Keutgen, A.J.; Wszelaczyńska, E.; Pobereżny, J.; Kozera, W.; Knapowski, T.; Mozolewski, W. Właściwości prozdrowotne marchwi (Daucus carota L.) jako funkcja odmiany oraz stosowania użyźniacza UGmax. Ekol. Technol. 2015, 23, 206-210. (In Polish)

4. Leja, M.; Kamińska, I.; Kramer, M.; Maksylewicz-Kaul, A.; Kammerer, D.; Carle, R.; Baranski, R. The content of phenolic compounds and radical scavenging activity varies with carrot origin and root color. Plant Foods Hum. Nutr. 2013, 68, 163-170. [CrossRef] [PubMed]

5. Jihong, W.; Haiyan, G.; Lei, Z.; Xiaojun, L.; Fang, C.; Zhnefu, W.; Xiaosong, H. Chemical com-positional characterization of some apple cultivars. Food Chem. 2007, 103, 88-93. [CrossRef]

6. Perera, C.O. Selected quality attributes of dried foods. Dry. Technol. 2005, 23, 717-730. [CrossRef]

7. Pellegrini, N.; Simonetti, P.; Gardana, C.; Brenna, O.; Brighenti, F.; Pietta, P. Polyphenol content and total antioxidant activity of vini novelli (young red wines). J. Agric. Food Chem. 2000, 48, 732-735. [CrossRef]

8. Di Mola, I.; Ottaiano, L.; Cozzolino, E.; Senatore, M.; Giordano, M.; El-Nakhel, C.; Mori, M. Plant-based biostimulants influence the agronomical, physiological, and qualitative responses of baby rocket leaves under diverse nitrogen conditions. Plants 2019, 8, 522. [CrossRef]

9. Szczepanek, M.; Siwik-Ziomek, A. P and K accumulation by rapeseed as affected by biostimulant under different NPK and S fertilization doses. Agronomy 2019, 9, 477. [CrossRef]

10. Szczepanek, M.; Wszelaczyńska, E.; Pobereżny, J.; Ochmian, I. Response of onion (Allium cepa L.) to the method of seaweed biostimulant application. Acta Sci. Pol. Hortorum Cultus 2017, 16, 113-122.

11. Alam, M.Z.; Braun, G.; Norrie, J.; Hodges, D.M. Ascophyllum extract application can promote plant growth and root yield in carrot associated with increased root-zone soil microbial activity. Can. J. Plant Sci. 2014, 94, 337-348. [CrossRef] 
12. Szczepanek, M.; Wilczewski, E.; Pobereżny, J.; Wszelaczyńska, E.; Ochmian, I. Carrot root size distribution in response to biostimulant application. Acta Agric. Scand. Sect. B Soil Plant Sci. 2017, 67, 334-339. [CrossRef]

13. Wszelaczyńska, E.; Szczepanek, M.; Pobereżny, J.; Kazula, M. Effect of biostimulant application and long-term storage on the nutritional value of carrot. Hortic. Bras. 2019, 37, 451-457. [CrossRef]

14. Pobereżny, J.; Szczepanek, M.; Wszelaczyńska, E.; Prus, P. The quality of carrot after field biostimulant application and after storage. Sustainability 2020, 12, 1386. [CrossRef]

15. Plant Growth in Harmony with Nature. Available online: https://www.kelpak.com/ (accessed on 6 November 2020).

16. Anyszka, Z. Metodyka integrowanej produkcji marchwi. Na podstawie art. 57 ust. 2 pkt 2 ustawy z dnia 8 marca 2013 r. o środkach ochrony roślin. In (Dz.U. z 2018 r. poz. 1310) Zatwierdzona przez Głównego Inspektora Ochrony Roślin i Nasiennictwa; Instytut Ogrodnictwa: Warszawa, Poland, 2018. (In Polish)

17. Keutgen, A.J.; Pawelzik, E. Modifications of strawberry fruit antioxidant pools and fruit quality under $\mathrm{NaCl}$ stress. J. Agric. Food Chem. 2007, 55, 4066-4072. [CrossRef]

18. Kalapathy, U.; Proctor, A. Effect of acid extraction and alcohol precipitation conditions on the yield and purity of soy hull pectin. Food Chem. 2001, 73, 393-396. [CrossRef]

19. Griffiths, D.W.; Bain, H.; Dale, M.F.B. Development of rapid colorimetric method for the determination of chlorogenic acid in freezedried potato tubers. J. Sci. Food Agric. 1992, 58, 41-48. [CrossRef]

20. Woisky, R.G.; Salatino, A. Analysis of propolis: Some parameters and procedures for chemical quality control. J. Apic. Res. 1998, 37, 99-105. [CrossRef]

21. Cheng, G.W.; Breen, P.J. Activity of phenylalanine ammonia-lyase (PAL) and concentrations of anthocyanins and phenolics in developing strawberry fruit. J. Am. Soc. Hortic. Sci. 1991, 116, 865-869. [CrossRef]

22. Dean, B.B.; Jakowiak, N.; Nagle, M.; Pavek, J.; Corsini, D. Blackspot pigment development of resistant and susceptible Solanum tuberosum L. genotypes at harvest and during storage measured by three methods of evaluation. Am. Potato J. 1993, 70, 201-217. [CrossRef]

23. Benzie, I.F.; Strain, J.J. The Ferric Reducing Ability of Plasma (FRAP) as a measure of "antioxidant power": The FRAP assay. Anal. Biochem. 1996, 239, 70-76. [CrossRef] [PubMed]

24. Re, R.; Pellegrini, N.; Proteggente, A.; Pannala, A.; Yang, M.; Rice-Evans, C. Antioxidant activity applying an improved ABTS radical cation decolorization assay. Free Radic. Biol. Med. 1999, 26, 1231-1237. [CrossRef]

25. Keutgen, A.; Pobereżny, J.; Wszelaczyńska, E.; Murawska, B.; Spychaj-Fabisiak, E. Wpływ przechowywania na procesy ciemnienia bulw ziemniaka (Solanum tuberosum L.) i ich właściwości prozdrowotne. Inż. Ap. Chem. 2014, 53, 86-88. (In Polish)

26. Colla, G.; Hoagland, L.; Ruzzi, M.; Cardarelli, M.; Bonini, P.; Canaguier, R.; Rouphael, Y. Biostimulant action of protein hydrolysates: Unraveling their efects on plant physiology and microbiome. Front. Plant Sci. 2017, 8, 2202. [CrossRef]

27. Wszelaczyńska, E. Wpływ nawożenia magnezem na zawartość kwasów organicznych i ciemnienie miąższu bulw ziemniaka odmiany Mila. Acta Sci. Pol. Agric. 2004, 3, 175-186. (In Polish)

28. Koley, T.K.; Singh, S.; Khemariya, P.; Sarkar, A.; Kaur, C.; Chaurasia, S.N.S.; Naik, P.S. Evaluation of bioactive properties of Indian carrot (Daucus carota L.): A chemometric approach. Food Res. Inter. 2014, 60, $76-85$. [CrossRef]

29. Sun, T.; Simon, P.W.; Tanumihardjo, S.A. Antioxidant phytochemicals and antioxidant capacity of biofortified carrots (Daucus carota L.) of various colors. J. Agric. Food Chem. 2009, 57, 4142-4147. [CrossRef]

30. Singh, B.K.; Koley, T.K.; Maurya, A.; Singh, P.M.; Singh, B. Phytochemical and antioxidative potential of orange, red, yellow, rainbow and black coloured tropical carrots (Daucus carota subsp. sativus Schubl. \& Martens). Physiol. Mol. Biol. Plants 2018, 24, 899-907. [CrossRef]

31. Yangilar, F. The Application of Dietary Fibre in Food Industry: Structural Features, Effects on Health and Definition, Obtaining and Analysis of Dietary Fibre: A Review. J. Food Nutr. Res. 2013, 1, 13-23. [CrossRef]

32. Prasanna, V.; Prabha, T.N.; Tharanathan, R.N. Fruit ripening phenomena-An overview. Crit. Rev. Food Sci. Nutr. 2007, 47, 1-19. [CrossRef]

33. Ertani, A.; Schiavon, M.; Nardi, S. Transcriptome-wide identification of diferentially expressed genes in Solanum Lycopersicon, L. in response to an alfalfa-protein hydrolysate using microarrays. Front. Plant Sci. 2017, 8, 1159. [CrossRef] [PubMed]

34. Sra, S.K.; Sandhu, K.S.; Ahluwalia, P. Effect of treatments and packaging on the quality of dried carrot slices during storage. J. Food Sci. Technol. 2014, 51, 645-654. [CrossRef] [PubMed] 
35. Arscott, S.A.; Tanumihardjo, S.A. Carrots of many colors provide basic nutrition and bioavailable phytochemicals acting as a functional food. Compr. Rev. Food Sci. Food Saf. 2010, 9, 223-239. [CrossRef]

36. Wang-Pruski, G.; Nowak, J. Potato after-cooking darkening. Am. J. Potato Res. 2004, 81, 7-16. [CrossRef]

37. Singh, D.P.; Beloy, J.; McInerney, J.K.; Day, L. Impact of boron, calcium and genetic factors on vitamin C, carotenoids, phenolic acids, anthocyanins and antioxidant capacity of carrots (Daucus carota). Food Chem. 2012, 132, 1161-1170. [CrossRef] [PubMed]

38. Kreutzmann, S.; Christensen, L.P.; Edelenbos, M. Investigation of bitterness in carrots (Daucus carota L.) based on quantitative chemical and sensory analyses. LWT Food Sci. Technol. 2008, 41, 193-205. [CrossRef]

39. EL Boukhari, M.E.; Boukhari, M.; Barakate, M.; Youness Bouhia, Y.; Lyamlouli, K. Trends in Seaweed Extract Based Biostimulants: Manufacturing Process and Beneficial Effect on Soil-Plant Systems. Plants 2020, 9, 359. [CrossRef]

40. Al-Ghamdi, A.A.; Elansary, H.O. Synergetic effects of 5-aminolevulinic acid and Ascophyllum nodosum seaweed extracts on Asparagus phenolics and stress related genes under saline irrigation. Plant Physiol. Biochem. 2018, 129, 273-284. [CrossRef]

41. Ahmad, T.; Cawood, M.; Iqbal, Q.; Ariño, A.; Batool, A.; Tariq, R.M.S.; Akhtar, S. Phytochemicals in Daucus carota and Their Health Benefits. Foods 2019, 8, 424. [CrossRef]

42. Surjadinata, B.B.; Cisneros-Zevallos, L. Biosynthesis of phenolic antioxidants in carrot tissue increases with wounding intensity. Food Chem. 2012, 134, 615-624. [CrossRef]

43. Hager, T.J.; Howard, L.R. Processing effects on carrot phytonutrients. Hortic. Sci. 2006, 41, 74-79. [CrossRef]

44. Akhtar, S.; Rauf, A.; Imran, M.; Qamar, M.; Riaz, M.; Mubarak, M.S. Black carrot (Daucus carota L.), dietary and health promoting perspectives of its polyphenols: A review. Trends Food Sci. Technol. 2017, 66, 36-47. [CrossRef]

45. Sharma, K.D.; Karki, S.; Thakur, N.S.; Attri, S. Chemical composition, functional properties and processing of carrot-A review. J. Food Sci. Technol. 2012, 49, 22-32. [CrossRef]

46. Bartley, G.E.; Avena-Bustillos, R.J.; Du, W.-X.; Hidalgo, M.; Cain, B.; Breksa, A.P. Transcriptional regulation of chlorogenic acid biosynthesis in carrot root slices exposed to UV-B light. Plant Gene 2016, 7, 1-10. [CrossRef]

47. Augšpole, I.; Kince, T.; Cinkmanis, I. Changes of polyphenol compound concentrations in hybrids of nante type carrots during storage. Proceedings of the Latvian Academy of Sciences. Sect. B. Nat. Exact Appl. Sci. 2017, 71, 492-495. [CrossRef]

48. Søltoft, M.; Nielsen, J.; Holst Laursen, K.; Husted, S.; Halekoh, U.; Knuthsen, P. Effects of organic and conventional growth systems on the content of flavonoids in onions and phenolic acids in carrots and potatoes. J. Agric. Food Chem. 2010, 58, 10323-10329. [CrossRef]

49. Bahorun, T.; Luximon-Ramma, A.; Crozier, A.; Aruom, O.I. Total phenol, flavonoid, proanthocyanidin and vitamin C levels and antioxidant activities of Mauritian vegetables. J. Sci. Food Agric. 2004, 84, 1553-1561. [CrossRef]

50. Ranjitha, K.; Rao, D.S.; Shivashankara, K.S.; Oberoi, H.S.; Roy, T.K.; Bharathamma, H. Shelf-life extension and quality retention in fresh-cut carrots coated with pectin. Innov. Food Sci. Emerg. Technol. 2017, 42, 91-100. [CrossRef]

51. Lazcano, C.A.; Yoo, K.S.; Pike, L.M. A method for measuring anthocyanins after removing carotenes in purple colored carrots. Sci. Hortic. Amst. 2001, 90, 321-324. [CrossRef]

52. Kammerer, D.; Carle, R.; Schieber, A. Detection of peonidin and pelargonidin glycosides in black carrots (Daucus carota ssp. sativus var. atrorubens Alef.) by high-performance liquid chromatography/electrospray ionization mass spectrometry. Rapid Commun. Mass Spectrom. 2003, 17, 2407-2412. [CrossRef] [PubMed]

53. Cefola, M.; Carbone, V.; Minasi, P.; Pace, B. Phenolic profiles and postharvest quality changes of fresh-cut radicchio (Cichorium intybus L.): Nutrient value in fresh vs. stored leaves. J. Food Compos. Anal. 2016, 51, 76-81. [CrossRef]

54. Christensen, L.P.; Brandt, K. Bioactive polyacetylenes in food plants of the Apiaceae family: Occurrence, bioactivity and analysis. J. Pharm. Biomed. Anal. 2006, 41, 683-693. [CrossRef] [PubMed]

55. Kidoń, M.; Czapski, J. Ocena zmian zawartości składników bioaktywnych oraz zdolności antyoksydacyjnej soków z marchwi purpurowej podczas przechowywania (Assessment of the changes in the bioactive components and anti-oxidizing properties of black carrot juice during storage). Bromat. Chem. Toksykol. 2009, 3, 848-853. (In Polish) 
56. Koley, T.K.; Kaur, C.; Nagal, S.; Walia, S.; Jaggi, S.; Sarika, J. Antioxidant activity and phenolic content in genotypes of Indian jujube (Zizyphus mauritiana Lamk). Arab. J. Chem. 2011, 9, 1044-1052. [CrossRef]

Publisher's Note: MDPI stays neutral with regard to jurisdictional claims in published maps and institutional affiliations.

(C) 2020 by the authors. Licensee MDPI, Basel, Switzerland. This article is an open access article distributed under the terms and conditions of the Creative Commons Attribution (CC BY) license (http://creativecommons.org/licenses/by/4.0/). 